\title{
Олень как образ национальной картины мира оленного народа
}

\author{
Габышева Д., ученица, \\ ГБОУ РС (Я) «ЭШИ Арктика», \\ 2. Нерюнгри
}

Научный руководитель: Егорова М.B.

Северный олень был одомашнен человеком много тысяч лет назад. Издавна оленеводством занимались малочисленные народы: эвены, эвенки, юкагиры, чукчи, долганы. Олень кормит, одевает, возит людей - выручает в трудные моменты. Олень даёт человеку мясо, молоко, одежду, обувь, материал для обустройства жилища. Из оленьей кожи выделывают замшу - ровдугу. Седло набивают шерстью оленя. Из рогов и костей оленя изготавливают различные поделки и сувениры.

Путешественники не раз писали в своих воспоминаниях о многочисленных стадах северных оленей. Петр Паллас, один из первых исследователей животного мира России, писал, что стада северных оленей движутся иногда без остановки в течение двух- трех суток.

Другой исследователь Севера, русский путешественник Фердинанд Врангель, описывал стада северных оленей длиною до ста верст. Некоторые путешественники заявляли, что видели оленьи стада, состоявшие по очень приблизительным подсчетам из 15-25 миллионов голов. И все, кто видел северных оленей, отмечали их красоту и величавость идущего стада. Олени обычно идут плотно. Высоко подняв рогатые головы, и кажется, будто движется густой и ветвистый.

В настоящее время сохранение, возрождение оленных народов возможны лишь при развитии национального самосознания подрастающего поколения, основой которого является олень, как образ национальной картины мира коренных народов Севера - оленных народов. Отношение к оленям - это и есть мерило достоинства настоящего Северного человека. У оленных народов раньше существовал обычай посвящать животных белой масти небесному богу - Кудьаю. Эвены таких оленей называют кудьай. - это, несомненно, покровитель человека от лица небесного божества Кудьай. Кудьая имели все члены семьи, рода. Кудьая специально выбирают из множества оленей более опытные оленеводы. Это старики или отцы семейства, а раньше в старину кудьая выбирали шаманы. Не каждый олень мог стать кудьаем, а именно олень с божественной отметиной, белой или пестрой масти, т.е. такие, говорят, которые имеют Тигок. Тигок - это комок волос, который иногда встречается под кожей на шее у оленей. Из него эвены делали волосяную веревку для дэлбургэ. Этот комок хранился в особой вьючной суме - һэруклэ, так как считалось, что он приносит счастье хозяевам. Когда кто-нибудь в их роду заболеет, будь то мужчина, женщина или ребенок, то по указанию шамана приводят к ним священного оленя. Если болит спина, лечит легким дуновением дыхания священного животного в то именно место спины, где болит, колет. Оленя кудьая никто не имел права использовать верхом, запрягать в нарты, навьючивать грузы. Он полностью освобождался от всяких работ до конца дней своих. Олень Кудьай - это покровитель человека, семьи, оленьего стада. 


\section{Наставления - обереги}

Собери подшейную шерсть оленя, чтобы не была разбросана, чтобы олени возвращались.

- $\quad$ Беременная женщина не может наступать на недоуздок.

- $\quad$ Не подходи к вьючному седлу табуированного оленя, может заболеть.

- Для роженицы не забивают старого оленя, забивают молодого. У старого тяжелое дыхание. Если женщина поест его мясо, долго будет болеть.

- Женщине нельзя есть мясо с поясничных позвонков, зверь не будет попадаться охотнику.

- $\quad$ Если волк зарежет оленя, его не берут, бросают.

\section{Заповеди оленевода}

- Устраивая свою жизнь, всегда в первую очередь думай, и поступай так, чтобы было хорошо и удобно твоим оленям и оленятам; и только во вторую очередь думай о себе и о своих детях. Помни: если сегодня хорошо вашим оленям, то завтра будет хорошо вам.

- Если у оленевода в стаде до 30 оленей, он - безоленный, от 30 до 300 малооленный, более 300 оленей - оленный.

- Хорошая невеста стоит 40 оленей, а снегоход от 10 до 15 оленей.

- Оленя можно купить, выпросить, взять напрокат, взять взаймы. Но не красть.

- Если ты вырастил стадо, не жадничай, подари оленя хорошему оленю, помоги нуждающемуся, безоленному.

- Но не перестарайся, никогда не подрубай основу, корень твоего стада. Вот теперь твое стадо больше принадлежит твоим детям и внукам, чем тебе.

\section{Олень в творчестве Северных писателей}

Тема оленя является доминирующей в молодой литературе Севера: поэтической, прозаической, лирической, авторской. Ибо она опирается на устное народное творчество, берущее свое начало из глубины веков. Многие века народы Севера жили изолированно, не имели письменности, оставаясь привязанным к собственному устному народному творчеству. Несмотря на изолированность фольклора в прошлом, тема оленя была главной для всех северных народов.

Одним из первых жанров молодой литературы севера является лирика. Она охватывает все области жизни народа, так как берет свои корни из древней традиции, по которой у каждого человека существовала «своя личная песня». Каждый охотник, сидя на верховом олене, воспевал красоту природы, признавался в любви девушке, ну и, конечно же, воспевал красоту, верность, грациозность оленя, главного помощника и друга.

Тема оленя проходит «красной нитью» через все виды, формы и жанры творчества северян - с глубокой древности до наших дней.

В произведениях таких, писателей как Андрей Кривошапкин, Николай Оегир, Василий Лебедев, Николай Курилов отношения к оленям это и есть мерило достоинства настоящего северного человека.

В фольклоре герои сказок или преданий, охотясь на оленей, уямканов, никогда не истребляли все стадо, если даже такая возможность была. Они знали, что, только оставив часть стада, можно рассчитывать на дальнейшую жизнь. Образ волшебного белого оленя проходит через все произведения Северных писателей, их произведения радостны, солнечны, мудры, навеяны народными традициями. 
Список литературы:

1. Алексеев А.А. Забытый мир предков [Текст] / А.А. Алексеев. - Якутск: КИФ «СИТИМ», 1993.

2. Демонстрационный проект «Экологический соменеджмент» ресурсодобывающих, органов власти и коренных малочитсленных народов Севера [Текст]. - М., 2009.

3. Дудкин Х.И. Эвенский фольклор [Текст] / Х.И. Дудкин. - Якутск: КИФ «СИТИМ», 1996.

4. Кривошапкин А.В. Кочевье длиной в жизнь [Текст] / А.В. Кривошапкин. - Якутск: НКИ «БИЧИК», 2000.

5. Кривошапкин А.В. Земля предков [Текст] / А.В. Кривошапкин. - Якутск: КИФ «СИТИМ», 1995.

6. Марфусалов Н.Е. Традиционная культура эвенков [Текст] / Н.Е. Марфусалов. - НКИ «БИЧИК», 2005.

7. Марфусалова А.Д. Мудрость экотрадиций северян [Текст] / А.Д. Марфусалова. - Якутск: НКИ «БИЧИК», 2002.

8. Никитина Р.С., Федоров, Г.Н., Винокурова Е.И. Умение жить на Севере [Текст] / Р.С. Никитина, Г.Н. Федоров, Е.И. Винокурова. - Якутск: НКИ «БИЧИК», 2011.

9. Петрова С.М. Эвенская литература [Текст] / С.М. Петрова. - СПб.: Просвещение, 1994.

10. Романова А.В., Мыреева А.Н. Фольклор эвенков Якутии: монография [Текст] / А.В. Романова, А.Н. Мыреева. - СПб.: Наука, 1971.

11. Степанова С.Р. Словарь оленеводческих терминов эвенков Алданского района [Текст] / С.Р. Степанова. - Якутск: НКИ «БИЧИК», 2009.

12. Шаманизм как религия [Текст]. - Якутск: КИФ «СИТИМ», 1992.

13. Сайт «Юридическая антропология» - [Электронный ресурс].- URL: http://www.jurant.ru/ru/publications/reindeer_disc/olen/klokov.html

14. Оленеводство в России/ Сайт «АрктикИнфо». - [Электронный ресурс] URL: http://www.arctic-info.ru/Encyclopedia/Article/olenevodstvo-v-rossii-

15. Галкин В.С. Оленеводство/ Большая Советская энциклопедия [Электронный ресурс]. - URL: http://dic.academic.ru/dic.nsf/bse/116079/Оленеводство

\section{Колхозное хозяйство в 1938-1941 годы на примере Якутской АССР}

Герасимов А.Г., студент, Северо-Восточный федеральный университет, 2. Якутск

E-mail: sakhastan1@mail.ru

Научные руководители: к.и.н. Акимова В.С., стариий преподаватель Андреев А.П.

Целью данной работы, является освещение состояния сельского хозяйства Якутской АССР в предвоенные годы (1938 - 1941 гг.). Надо отметить, что этот вопрос 